\title{
Filozoficzne podstawy systemu pedagogicznego zmartwychwstańców w pismach Piotra Semenenki**
}

Praktyka edukacyjna staje się coraz bardziej docenianym elementem obszaru zainteresowań pedagogiki naukowej, nie tylko jako miejsce aplikacji założeń, celów, idei wypracowanych przez jej teorie, nurty i koncepcje, ale także jako przedmiot badań pedagogiki jako nauki ${ }^{1}$, jedno z jej źródeł, a także uzasadnienie współczesnego naukowego myślenia o edukacji². Pedagogie $^{3}$ są ważną częścią zarówno historycznej, jak i współczesnej rze-

* Dr Dominika Katarzyna Jagielska jest asystentem w Zakładzie Pedagogiki Szkoły Wyższej Uniwersytetu Jagiellońskiego w Krakowie.

**Temat: Filozoficzne podstawy wychowania w pismach twórców systemu pedagogicznego zmartwychwstańców, został zgłoszony przez J. Kostkiewicz jako referat na konferencję: Misja butgarska zmartwychwstańców: 150 lat w stużbie Kościołowi i społeczeństwu (Program Konferencji, Kraków, 19 lutego 2013 r.). Niniejszą jego część (wersję) opracowałam na podstawie przekazanych mi materiałów źródłowych.

1 T. Hejnicka-Bezwińska, Pedagogika ogólna, Warszawa 2008, s. 220.

2 Por. tamże, s. $220 \mathrm{n}$.

${ }^{3}$ W rozumieniu Stefana Możdżenia pedagogie to zbiory idei traktujące o wychowankach, wychowawcach, samym procesie wychowania oraz pewnym ogólnym programie oddziaływań intelektualnych i moralnych. Teresa Hejnicka-Bezwińska określa je z kolei jako sztukę skutecznego działania na dzieci dla osiagnięcia wybranych celów lub też jako paradygmat edukacyjny (doktryna, ideologia, ukryty program), lub też zbiór praktyk edukacyjnych, dzięki którym jednostka przyswaja wiedzę, umiejętności, postawy od osoby lub osób uznawanych przez nią za autorytet. Zob. S. Możdżeń, Pedagogia ojców i pisarzy Kościoła, w: T. Pilch (red.), Encyklopedia pedagogiczna XXI wieku, t. 4, Warszawa 2005, s. 88; T. Hejnicka-Bezwińska, dz. cyt., s. 493. 
czywistości edukacyjnej i społecznej, to one i ich przedstawiciele bowiem wychowują i kształca, znajdują się najbliżej wychowanka, współtworząc życie codzienne jednostek oraz społeczne grup i wspólnot. Czerpią przy tym z pewnych założeń: filozoficznych, religijnych, ideologicznych, światopoglądowych czy naukowych ${ }^{4}$, związanych z miejscem i czasem ich występowania, które to wyznaczają preferowane przez nie cele i zasady wychowania i kształcenia, stosowane metody i środki, role wychowawców i wychowanków.

Jednymi z ważniejszych i szczególnie interesujących dla współczesnej cywilizacji pedagogii sa praktyki edukacyjne inspirowane filozofią i teologią, zwłaszcza społeczną nauką Kościoła katolickiego, który od wczesnego średniowiecza do XIX wieku wiódł prym w wychowaniu i kształceniu dzieci i młodzieży, a dziś jest ważnym organizatorem zróżnicowanych działań w tym obszarze działalności ludzkiej. Zwłaszcza pedagogie zgromadzeń zakonnych wydają się współcześnie obszarem o dużym znaczeniu dla praktyki edukacyjnej, a jednocześnie słabo znanym szerszym kręgom akademickim i społecznym. Doczekały się one wprawdzie niedawno szerokiego opracowania $^{5}$, jednak bogactwo tej problematyki sprawia, że nie może zostać ona zamknięta czy uznana za w pełni rozpoznaną. Jednym z wątków, jakie warto poddać analizie i jaki został tematem niniejszych rozważań, jest kwestia filozoficznych podstaw działania wychowawczego zmartwychwstańców, zgromadzenia zakonnego o szczególnym znaczeniu dla Polski i Polaków głównie w XIX wieku i okresie międzywojennym ${ }^{6}$. Jednym zaś z najważniejszych

${ }^{4}$ W zależności od właściwości charakterystycznych dla pewnego określonego systemu idei oraz sposobu ich interpretacji przez osoby i grupy wprowadzające je w życie (kwestia otwartości i zamkniętości, podejścia refleksyjnego i fundamentalistycznego do danego zbioru idei, oparcia się o systemy filozoficzne i/lub wiedzę naukową lub o interesy grupy, jednostki, itp). Por. M. Malewski, Niepewność wiedzy - zawodność praktyki edukacyjnej, „Teraźniejszość - Człowiek - Edukacja” 4 (2002), s. 67; M. Kowalski, D. Falcman, Ideologie nauk spotecznych - warianty interpretacyjne, Kraków 2012, s. 14; P. Sztompka, Socjologia. Analiza społeczeństwa, Kraków 2004, s. 295-300.

${ }^{5}$ Por. J. Kostkiewicz (red.), Pedagogie katolickich zgromadzeń zakonnych. Historia i współczesność, t. 1, Kraków 2012; J. Kostkiewicz, K. Misiaszek (red.), Pedagogie katolickich zgromadzeń zakonnych. Historia i wspótczesność, t. 2, Kraków 2013.

${ }^{6}$ Głównie ze względu na wielkich Polaków, związanych z jego powołaniem, takich jak na przykład Adam Mickiewicz, a także patriotyczne inklinacje jego zaistnienia i podtrzymywania. Nie bez znaczenia pozostawało również poważanie, jakim cieszyli się założyciele zmartwychwstańców (Bogdan Jański, Piotr Semenenko, Hieronim Kajsiewicz) w kręgach naukowych oraz duchownych, także w Watykanie. Por. B. Żulińska, Z wychowawczej ideologii zmartwychwstańczej, „Ateneum Kapłańskie” 5 (1933), s. 329-346, 474-489; J. Iwicki, Charyzmat zmartwychwstańców. Historia Zgromadzenia Zmartwychwstania Pańskiego, t. 1, Katowice 1990; t. 2, Kraków-Kielce 2007; J. Kostkiewicz, Zgromadzenie Zmartwychwstania Pańskiego i jego system wychowawczy, w: taż (red.), dz. cyt., s. 309-334; taż, Misje eduka- 
twórców ontologicznych, epistemologicznych antropologicznych i logicznych fundamentów systemu pedagogicznego tego zgromadzenia był jeden z jego założycieli - Piotr Semenenko.

Zmartwychwstańcy stworzyli niewątpliwie oryginalny, autorski model pracy dydaktycznej i wychowawczej, oparty na wolności człowieka, promujący atmosferę swobody, odpowiedzialności oraz samorządności, zaangażowany, akcentujący zasadę miłości w pracy wychowawczej, stawiający za cel harmonijny rozwój każdej z władz człowieka (intelektu, woli, uczuć) ${ }^{7}$. Rozpoznanie jego filozoficznych fundamentów wydaje się ważne - odkrycie przesłanek, które przyczyniły się do specyficznego charakteru działalności pedagogicznej tego zgromadzenia, pozwala na lepsze zrozumienie jego celów i zasad, wartości dla praktyki edukacyjnej, odkrywa możliwości wdrożenia jego elementów lub całości w dzisiejszą rzeczywistość pedagogiczną. Jest również swoistym, dobrowolnym ,odkryciem kart” w okresie rozmywania się i zacierania pochodzenia promowanych idei lub ich zbiorów. Poza tym system filozoficzny P. Semenenki jest intrygujący z punktu widzenia czysto poznawczego, stanowiąc ciekawy przykład próby zreformowania tomizmu. Przedstawione poniżej refleksje stanowią jedynie bardzo ogólne przedstawienie podstawowych tez filozoficznych P. Semenenki, leżących u podstaw szeroko realizowanego później w Europie systemu pedagogicznego, niejako ich przypomnienie. Literatura na ten temat jest niewielka i w większości wiekowa, ale dostępna i wartościowa, niniejsza refleksja może być traktowana jedynie jako wprowadzenie w tę problematykę.

\section{Początki Zgromadzenia oo. Zmartwychwstańców}

Zgromadzenie to powstało po upadku powstania listopadowego wśród przedstawicieli polskiej Wielkiej Emigracji w Paryżu. Wśród jego założycieli wymienia się Bogdana Jańskiego, Piotra Semenenkę i Hieronima Kajsiewicza. Nie bez znaczenia była przynależność twórców zgromadzenia do założonego przez Adama Mickiewicza stowarzyszenia Braci Zjednoczonych. Zgromadzenie oo. Zmartwychwstańców zrodzone z nawrócenia religijnego jego założycieli oraz inspiracji patriotycznych miało propagować odnowienie katolickie w ideologicznie „rozpalonej” Europie, szczególnie w odniesieniu do Polaków, a także wspomagać ,zmartwychwstanie Polski” dzięki odnowie moralnej i zaufaniu sprawiedliwości Boga. Było to zgromadzenie zakonne polskie, prowadzące działalność misyjną w wielu krajach całego świata i roz-

cyjne $i$ ważniejsze instytucje oświatowo-wychowawcze zmartwychwstańców, w: tenże (red.), dz. cyt., s. 335-367.

${ }^{7}$ Por. tenże, Zgromadzenie, s. 318-333. 
wijające się przez długi okres czasu poza Polską (ze względu na interesy zaborców i charakter zgromadzenia), do dziś funkcjonuje, chociaż charakterystyczna dla niego działalność pedagogiczna uległa znacznemu ograniczeniu\&.

Reguła i zasady praktyki edukacyjnej wiązały się z zaistniałym w XIX wieku w Kościele katolickim ponowieniem zainteresowania filozofią tomistyczną. Oficjalny powrót Kościoła katolickiego do tomizmu jest związany z encykliką Aeterni Patris papieża Leona XIII z 1879 roku' ${ }^{9}$ która zachęca do ponownego odczytywania i twórczej refleksji nad dziełami św. Tomasza z Akwinu, uznając tomizm za filozofię reprezentatywną katolicyzmu i przyczyniając się do powstania opartej na niej pedagogiki tomistycznej. Jednak przyczyniły się do tego wcześniejsze zainteresowania uczonych tą filozofią, szczególnie obecne w myśli i praktyce edukacyjnej twórców systemu pedagogicznego ojców zmartwychwstańców, które między innymi znalazły swój wyraz w uprzedzającym encyklikę memoriale skierowanym do papieża, który stanowił wniosek o podjęcie idei rozwoju tego stanowiska filozoficznego i uczynienie go podstawą katolickiego oglądu świata. Wpływ założycieli Zgromadzenia O.O. Zmartwychwstańców na powrót do i ponowne odczytanie dzieł św. Tomasza oraz zastosowanie ich w praktyce pedagogicznej był w II połowie XX wieku i jest współcześnie niedoceniany ${ }^{10}$. Również w myśli pedagogicznej pedagogia zmartwychwstańcza jako sposób zastosowania w pracy wychowawczej filozofii tomistycznej jest pomijana - dosłownie i bez wskazania powodu takiego postępowania. Jak wskazuje Janina Kostkiewicz, Stefan Kunowski wprost pisze: „Pomijając prekursorskie zainteresowanie P. Semenenki zastosowaniem filozofii tomistycznej [...] jednym z pierwszych odkrywców znaczenia nauki św. Tomasza dla nauczania i wychowania był katolicki pedagog austriacki Otto Willmann"11. Tym bardziej jednak próba przybliżenia filozoficznych podstaw wypracowanego ( $\mathrm{w}$ teorii i praktyce) przez członków tego zgromadzenia systemu pedagogicznego wydaje się w pełni zasadna. Ich rola w naukowej eksploracji tomizmu i jej wpływ na filozofię wychowania powinny zostać przypomniane.

${ }^{8}$ Por. tamże, s. 309-334. Zainteresowanych szerszą wiedzą dotyczącą historii i działalności tego zgromadzenia odsyłam do powyżej wymienionego artykułu oraz poniższej przykładowej literatury. Por. B. Żulińska, dz. cyt.; J. Iwicki, dz. cyt., t. 1; tenże, dz. cyt., t. 2; J. Kostkiewicz, Misje, s. 335-367.

9 Leon XIII, Encyklika Aeterni Patris o studiach filozoficznych, Warszawa 1902.

${ }^{10}$ Ich znaczenie i rolę na arenie międzynarodowej wskazuje Janina Kostkiewicz. Por. J. Kostkiewicz, Kierunki i koncepcje pedagogiki katolickiej w Polsce 1918-1939, Kraków 2013, s. $180-182$.

${ }^{11}$ S. Kunowski, Tomistyczne studia $w$ dziedzinie pedagogiki, w: Pastori et Magistro. Praca zbiorowa dla uczczenia 50-lecia kapłaństwa Ks. Bpa P. Kałwy, Lublin 1966, s. 469-488, za: J. Kostkiewicz, Kierunki, s. 180-182. 


\section{Teoria bytu w pismach Piotra Semenenki}

Rozpoczynając od sposobu istnienia rzeczy według P. Semenenki, wskazuje on na dwa aspekty bytu, rozróżniając formę (postać, wytwór) oraz jestestwo (treść, tworzywo). Forma i jestestwo są jednym, choć nie tym samym. W rzeczy rozróżnia zatem w rzeczywistości trzy odrębne składniki: formę, jestestwo oraz jedność, które wyznaczają również trzy stosunki czy względy pomiędzy nimi. Po pierwsze: każda forma należy do swojego jestestwa - stosunek pomiędzy formą a jestestwem nazywa należeniem. Po drugie: każde jestestwo ziści swoją formę - stosunek pomiędzy jestestwem a formą określa jako iszczenie. Po trzecie: każde jestestwo ze swoją formą i każda forma ze swoim jestestwem są jednym - są jednością ${ }^{12}$. Pojawia się tu zatem byt złożony i jednocześnie pozostający nierozerwalną całością dzięki relacjom pomiędzy jego poszczególnymi elementami.

W interpretacji Pawła Smolikowskiego, który tłumaczy rozumienie bytu P. Semenenki używając innych pojęć, są dwa pierwiastki istnienia: substancja i przypadłość, które nie mogą istnieć bez siebie nawzajem. Przypadłość tkwi w substancji i istnieje tylko pod warunkiem trwania stosunku przypadłości do substancji, którą nazywa tkwieniem. Substancja zaś służy przypadłości jako podmiot tkwienia, co jest warunkiem koniecznym istnienia substancji, a relacją między substancją a przypadłością jest podmiotowość. Z tych brzegowych stosunków wypływa stan równowagi i zjednoczenia przypadłości i substancji, wspólnoty, wzajemnego przenikania się relacji tkwienia i podmiotowości, tworzący każdą istotę istniejąca, byt: stosunek utożsamienia. A zatem według P. Smolikowskiego P. Semenenko wyróżnia trzy składniki rzeczy: jestestwo, jego formę i siłę łącząca je w jedno ${ }^{13}$. Jednak stosunek jedności czy utożsamienia nie jest równoważny tożsamości dwóch pierwszych składników bytu. Jak pisze T. Kaszuba: ,jedność jest możliwa tylko między różnymi elementami: takimi właśnie są jestestwo i forma"14. Na schemacie (Schemat 1.) można zobaczyć próbę graficznego opracowania koncepcji bytu P. Semenenki i jej interpretacji dokonanej przez P. Smolikowskiego.

12 Por. P. Semenenko, Biesiady filozoficzne, „Przegląd Poznański” 27 (1859), s. 113-147 .

13 Por. P. Smolikowski, System filozoficzny X. Piotra Semenenki, „Przegląd Kościelny” 27 (1904), s. 200-209, 29 (1904), s. 339-371.

${ }^{14}$ T. Kaszuba, Trójpodziat jako zasada istnienia i poznawania rzeczywistości, Rzym 2009, http://www.biz.xcr.pl/files/Kaszuba-Trojpodzial.pdf, z dn. 20 lipca 2013 r, s. 3. 


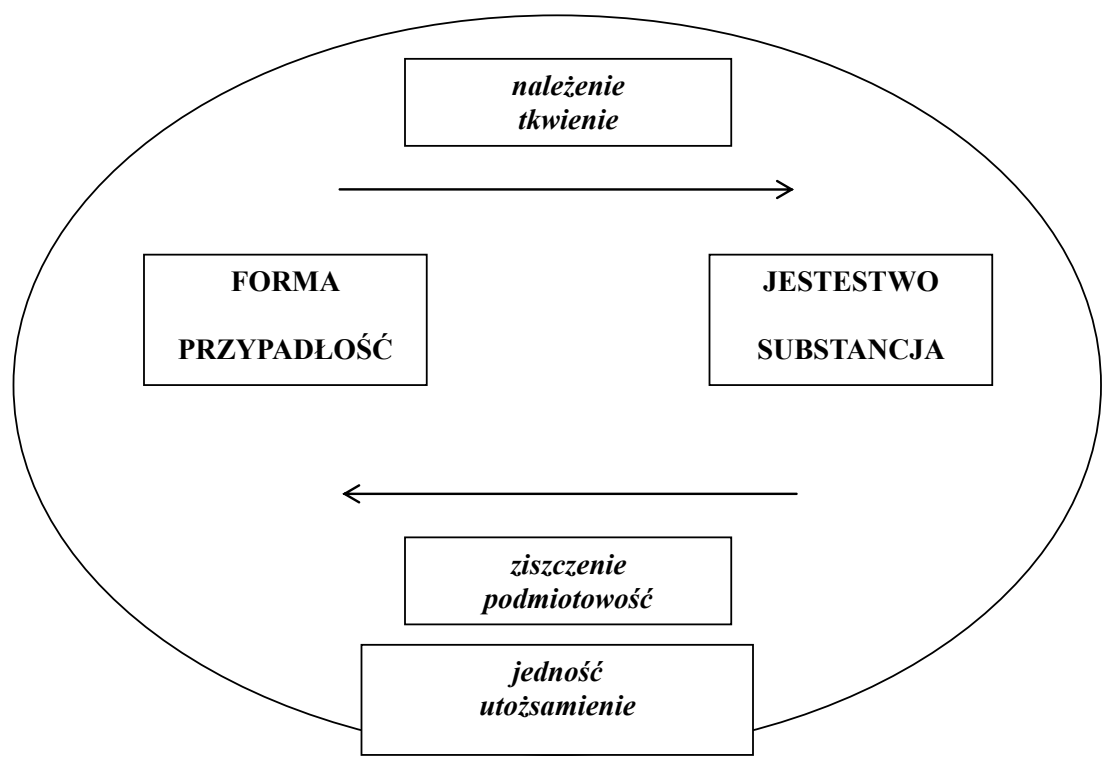

Schemat 1. Składniki rzeczy (bytu) według P. Semenenki CR i w interpretacji P. Smolikowskiego CR

Trójdzielna interpretacja bytu wydaje się być fundamentem całej koncepcji P. Semenenki, który stosuje ją tłumacząc zarówno istotę bytu, jak i poznania, a jej reminiscencje można odnaleźć także w jego koncepcji człowieka. Niemniej jednak należałoby zaznaczyć za T. Kaszuba, że wśród pism P. Semenenki brak jest takich, które jednoznacznie i bezpośrednio odnoszą się do metafizyki. Poza tym jego teoria bytu jest funkcją teorii poznania, która stanowi najbardziej wartościową i kluczową część twórczości jednego z założycieli Zgromadzenia oo. Zmartwychwstańców ${ }^{15}$. Jak podkreśla T. Kaszuba, trójpodział jest centralnym zagadnieniem filozofii P. Semenenki, stanowiącym klucz do odczytania innych poruszanych przez niego kwestii ${ }^{16}$.

\section{Teoria poznania w pismach Piotra Semenenki}

Przyglądając się teorii poznania P. Semenenki, można wskazać na dwa jej ważne momenty - definiowanie rozumu i w łączności z nim prawdy oraz

15 Por. tenże, Semenenki koncepcja filozofii jako racjonalnego poznania, Rzym 1985, s. 5. Wychodzę od krótkiego opisu kwestii metafizycznych z chęci zachowania pewnej logiki wywodu.

16 Por. tenże, Trójpodziat, s. 1. 
Filozoficzne podstawy systemu pedagogicznego zmartwychwstańców... 151

wskazanie na sposób, w jaki rozum ludzki poznaje rzeczywistość. Według P. Semenenki rozum jest władzą myślenia, podstawą, gruntem czy tworzywem (zatem jestestwem), sama myśl zaś jest wytworem rozumu, jego postacią (zatem formą) ${ }^{17}$. Człowiek dzięki rozumowi potrafi odkrywać prawdę. Jak pisze P. Semenenko: „natura ludzka jest tak usposobiona, że czyni człowieka zdolnym do poznania prawdy: odpowiednią zaś władzą natury ludzkiej, narzędziem do poznania prawdy, naczyniem do zatrzymania poznanej, jest rozum. Ale rozmaite są sposoby, któremi rozum prawdę poznaje"18. Definicję prawdy zaś zawiera w formule: „,prawdą jest to, co jest, jeśli jest tak, jak ma być" 19 . W interpretacji F. Gabryla obecne są tutaj dwa stwierdzenia - prawda jest to, co jest - twierdzenie główne i - jeśli jest, jak ma być - twierdzenie poboczne. Pierwsze wskazuje zależność ziszczenia prawdy w formie, w drugim widoczne jest należenie formy do prawdy. Zatem można powiedzieć za F. Gabrylem, że prawda według P. Semenenki jest to forma rzeczy, jeśli ta forma jest taka, jakie jest jej jestestwo. Prawda ma znaczenia jednocześnie jednorazowości i następstwa: istoty mogą od razu iścić swoją formę lub iścić ją z pewnym następstwem (na przykład rośliny, których ziarno lub kiełek iści prawdziwą i pełną formę w przyszłości) ${ }^{20}$.

Wiedza jest formą rozumu, ale przychodzi ona poprzez twierdzenia pochodzące z zewnątrz: wyobrażenia o rzeczy, mające swoje źródło w innym „rozumie”, jaki mamy wspólny ze zwierzętami; wyobraźni, która postrzega jedynie zewnętrzne właściwości rzeczy, formę, nie docierając do jestestwa $^{21}$. Prawda zatem może być według P. Semenenki wewnętrzna - gdy polega na zgodności twierdzenia $\mathrm{z}$ rozumem, oraz zewnętrzna - gdy jest zgodnością wiedzy i twierdzenia (kiedy takie jest twierdzenie, jaka wiedza). W Bogu prawda wewnętrzna i zewnętrzna jest zrównana w sposób jednorazowy i wieczny (Bóg myśli o sobie odróżniając siebie od innych rzeczy, jego rozum jest wszystkim, co można wiedzieć, sam z siebie rodzi formę, czyli wiedzę), w człowieku zaś prawda jest równowagą miedzy formą jego rozumu (czyli jego wiedzą obecną w czynie) a jestestwem jego rozumu (jego zdolnością myślenia i wiedzenia). Idea boża jest złożona jako wymaganie lub zadanie w jestestwie istoty o wolnej woli, a istota winna dać na nie odpowiedź w formie, do której przychodzi w procesie swojego rozwoju. Zatem

${ }^{17}$ Por. F. Gabryl, Polska filozofia religijna w wieku dziewiętnastym, t. 2, Poznań-Warszawa 1914, s. 211-216.

18 P. Semenenko, Credo, chrześcijańskie prawdy wiary, Kraków 1896, s. 6.

${ }_{19}$ Tenże, Biesiady filozoficzne, „Przegląd Poznański” 28 (1859), s. 52.

${ }^{20}$ Por. F. Gabryl, dz. cyt., s. 214-217.

${ }^{21}$ Por. P. Semenenko, Credo, s. 6. 
prawda człowieka i każdej istoty jest zrównaniem jej jestestwa i jej formy $\mathrm{z}$ jej ideą bożą ${ }^{22}$.

Warunkiem zajścia procesu poznania są trzy kwestie, które wskazują na zastosowanie również w epistemologii zasady trójpodziału. Jak wskazuje P. Semenenko:

w każdem podobnem poznawaniu trzech rzeczy potrzeba: Przedmiotu, czyli objektu, który my będziemy nazywali przedsobem poznawania, a tym jest wszystko, co względem rozumu jest na zewnątrz. Siebie samego, jako władzy czyli subjektu, który my będziemy nazywali wsobem poznawania, a tym jest rozum. Siły łączącej jedno z drugiem, która działa jako światło, i którą my będziemy nazywali światłem rozumu; tą zaś siłą są prawidła złożone w rozumie, i kierujące nim w akcie poznawania ${ }^{23}$.

Proces poznawania odzwierciedla zatem trzy momenty wyznaczające byt. Przebiega on w ten sposób, że w pierwszej chwili człowiek widzi formę, jakakolwiek ona jest (zupełna czy niedoskonała), z formy zaś wnioskuje na jestestwo, bo forma należy do jestestwa. Dochodząc do jestestwa, umysł patrzy ponownie na formę i sądzi ją według formuły, że jestestwo iści formę, rozważając czy jest ona zupełna, doskonała, zrealizowana czy też nie. Na koniec tworzy pełną myśl o przedmiocie aktu poznania zgodnie $\mathrm{z}$ formuła, iż jestestwo i forma są jednym. Zatem jestestwa rzeczy człowiek nie widzi bezpośrednio, nie może - jedynie wnosi na nie zgodnie $\mathrm{z}$ daną umysłowi formuła, zgodną ze sposobem istnienia rzeczy. Odczytuje więc z widzialnej, znanej formy, niewidzialne, nieznane jestestwo ${ }^{24}$, łącząc je w całość wynikającą ze względu jedności składników bytu.

Różnica między poznaniem człowieka i zwierzęcia według P. Semenenki jest więc taka, że zwierzę i człowiek poznają tylko formy i działania zewnętrzne rzeczy, ale zwierzę nie wie nic i nie może się dowiedzieć o jestestwie, a człowiek o jestestwie wie, ponieważ wyciagga nieomylny wniosek wynikający z pierwszej reguły bytu i logiki ${ }^{25}$. Myśl tę rozwija Stefan Pawlicki, który krytykując teorię Darwina, podkreśla, że różnica między zwierzęciem i człowiekiem nie jest różnicą stopnia, ale różnicą jakościową. Zaś myślenie i mowa to główne własności człowieka, których żadne zwierzę nie posiada, a zatem nie może być z nim spokrewnione ${ }^{26}$.

${ }_{22}$ Por. F. Gabryl, dz. cyt., s. 215-217.

${ }_{23}$ P. Semenenko, Credo, s. 7.

${ }^{24}$ Por. F. Gabryl, dz. cyt., s. 217-218.

${ }^{25}$ Por. tamże, s. 218.

26 S. Pawlicki, Człowiek i matpa, „Przegląd Lwowski” 3 (1872), s. 513-534, za: F. Gabryl, dz. cyt., s. 247-249. 
Filozoficzne podstawy systemu pedagogicznego zmartwychwstańców... 153

Warto tu zaznaczyć, iż troistość, będąca podstawą zarówno istnienia rzeczy, jak i myślenia (poznawania), znajduje również swoje zastosowanie w logice rozwijanej przez tego założyciela Zgromadzenia oo. Zmartwychwstańców. Według P. Semenenki istnieją bowiem trzy zasady w porządku logicznym, które wynikają z samego istnienia bytu i są wrodzone. Nawiązują one do relacji pomiędzy dwoma aspektami bytu: formą i jestestwem. Pierwsza zasada to zasada własności - forma należy do jestestwa, jest jego własnościa, druga zasada to zasada przyczynowości - jestestwo wydaje formę, trzecia - zasada tożsamości - czyli zrównoważenie obu ruchów myśli. Wszystkie łączą się w wyższej, zasadniczej regule, która tworzy zasadę absolutną oraz bezwzględną: pojęcie, w którym pojmujemy i myślimy, że coś jest $^{27}$. Proponowana przez P. Semenenkę logika jest więc konsekwencją przyjmowanych założeń ontologicznych i epistemologicznych.

$\mathrm{Na}$ podstawie tak określonego przebiegu procesu poznawania można sądzić, że umysł człowieka poznaje tylko formy. Jednak P. Semenenko próbuje tą kwestię rozwiązać odmiennie. Jak wskazuje F. Gabryl interpretując jego myśl, coś musi łączyć rozum z rzeczą poznawaną, według niego takim pomostem jest idea rzeczy. Idea nie jest wyobrażeniem, a rzeczą samą w sobie, wychodzi sama z siebie, ze stanu czystej idei, stając się rzeczą. Kiedy jednak staje się rzeczą, nie może już stać się ponownie ideą samą w sobie, jest jednym i tym samym co rzecz. Zatem idea prawdziwa jest rzeczą, a poza rzeczami jej nie ma. Poza tym forma rzeczy ma zawsze dwie strony. Przez wewnętrzną należy do jestestwa, przez zewnętrzną łączy się z władzą myślenia i objawia się innym. Zatem w swoim jestestwie forma stanowi rzecz, a w umyśle ją pojmującym - ideę ${ }^{28}$. Jak zatem zwraca uwagę T. Kaszuba, „rozumienie poznania dokonało się u Semenenki w nawiązaniu do tradycji arystotelesowskiej, według której poznanie polega na połączeniu się formy zastępczej rzeczy z formą osobistą intelektu"29. W myśli P. Semenenki można wyróżnić trzy sposoby rozumienia idei. Pierwszym jest idea (istnienie) realna, która istnieje uczestnicząc w bycie (rzeczy), drugim - idea (istnienie) formalna (logiczna), która przysługuje treści idei występującej w bycie, zawierającej wszystkie składniki i cechy należące do tej rzeczy ${ }^{30}$ (jak się wydaje, można to odnieść do rozumienia typu idealnego przez Maxa Webera $^{31}$ w tym sensie, że dotyczą wszelkich cech optymalnych, możliwych

27 Por. P. Smolikowski, System, s. 201.

${ }^{28}$ Por. P. Semenenko, Biesiady filozoficzne, „Przegląd Poznański” 28 (1859), s. 66-67;

F. Gabryl, dz. cyt., s. 219-220.

${ }_{29}$ T. Kaszuba, Semenenki, s. 11.

${ }^{30}$ Por. Tamże, s. 10-11.

${ }^{31}$ Por. P. Załęski Typy idealne w socjologii religii Maxa Webera: Analiza struktury kategoryzującej pole religijne, „Kultura i Społeczeństwo” 1 (2003), s. 45-51. 
i idealnych dla danego bytu). Po trzecie zaś, wymienia on istnienie idealne, inaczej ideę w sensie właściwym, którą rozumie jako świadome przeżycie istnienia realnego i formalnego rzeczy ${ }^{32}$.

\section{Koncepcja człowieka w pismach Piotra Semenenki}

W pismach P. Semenenki ukazana jest również koncepcja człowieka, która jest budowana $\mathrm{z}$ uwzględnieniem twierdzeń dotyczących bytu oraz poznania, a która stoi u podstaw całego systemu pedagogicznego zmartwychwstańców. Otóż, według tego założyciela zgromadzenia zmartwychwstańców człowiek posiada naturę, która składa się z substancji cielesnej oraz substancji duchowej, połączonych w jedno. Pierwsza z nich obejmuje władze zmysłowe ogniskujące się w sercu lub uczuciu, druga zaś - władze duchowe ogniskujące się w umyśle lub duchu. Właściwością substancji cielesnej jest czucie, zaś właściwością substancji duchowej - myślenie. Dusza jest jednym $\mathrm{z}$ władzami duchowymi, $\mathrm{z}$ władzami cielesnymi nie musi wiązać się zawsze i nieodwołalnie, ale pełni ważne funkcje w życiu człowieka: żyje duchem, nadaje życie ciału i łączy w jedno ludzkie życie jako zupełne i całe. Jest więc pierwiastkiem czynnym i formującym - siłą spajającą jestestwo i formę człowieka ${ }^{33}$. Stąd wskazuje P. Semenenko trzy dziedziny życia ludzkiego - dziedzinę ciała i uczucia, dziedzinę myśli i rozumu, oraz jednoczącą je dziedzinę woli i uczynków ${ }^{34}$. W każdej z nich rozróżnia trzy poziomy: powierzchnię, środek i władzę naczelną. W przypadku pierwszym powierzchnią jest ciało i jego zmysły, środkiem serce, władzą i siłą uczucie. W dziedzinie drugiej do tych grup kolejno należą: idee i myśli, umysł, władza wnioskowania, czyli rozum. Natomiast powierzchnią trzeciej dziedziny życia ludzkiego są postanowienia i uczynki, władzą naczelną wola, a środkiem dusza jako źródło uczynków, myślenia i życia. W duszy człowieka zaś osadzona jest osoba człowieka - według P. Semenenki natura jest tym, co mamy, natomiast osoba tym, czym jesteśmy ${ }^{35}$.

Podobny sposób interpretacji można zauważyć w pismach innego przedstawiciela zmartwychwstańców, Stefana Pawlickiego. Duszę widzi on jako substancję samoistną i duchową, wskazując, że nie można, jak chcą tego materialiści, utożsamiać duszy z samym działaniem ludzkiego mózgu. Stwierdza, że gdyby dusza była jedynie sumą czynności fizjologicznych

\footnotetext{
32 Por. T. Kaszuba, Semenenki, s. 10.

${ }^{33}$ Por. P. Semenenko, Credo, s. 51-52; tenże, Mistyka, Poznań 2009, s. 21-23.

${ }^{34}$ Tenże, Credo, s. 171

${ }^{35}$ Tenże, Mistyka, s. 23-24.
} 
Filozoficzne podstawy systemu pedagogicznego zmartwychwstańców... 155

tkanki nerwowej, myślenie i jego jakość byłyby powiązane wprost proporcjonalnie $\mathrm{z}$ wielkością mózgu, czego nie można $\mathrm{w}$ realnym świecie stwierdzić. Dusza jest połączona $\mathrm{z}$ ciałem w jedno, potrzebuje więc do swojego działania zdrowego mózgu, ale to nie znaczy, że tylko z niego wynika. Pojęcia, sądy, oceny, rozwaga, samowiedza, pamięć, wola, religijność - nie da się ich thumaczyć, odnosząc się tylko do procesów neurofizjologicznych, wszystkie muszą mieć przyczynę, która musi być jestestwem duchowym, niezawisłym i odmiennym od ciała, jak te wszystkie kwestie są od niego niezależne ${ }^{36}$. Dusza zatem będzie $\mathrm{w}$ tym rozumieniu czynnikiem powodującym jedność czy utożsamienie człowieka każdej części jego natury. Uzupełnieniem tej koncepcji jest również krytyka materializmu dokonana przez S. Pawlickiego ${ }^{37}$, który stwierdza, że materia nie jest i nie może być wieczna. Chociaż znamy tylko materię w ruchu, to jednak ruch zawsze ma swój koniec. Jeśli zaś ma koniec, to musi mieć i początek, a zatem materia musi mieć koniec i początek, swoją przyczynę i powód, których upatruje w Bogu.

Jednak P. Semenenko nie pozostaje w swojej koncepcji antropologicznej na pojęciach natury ludzkiej, osoby i duszy, a rozwija ją w stronę kolejnej ważnej właściwości człowieka - nadnatury. Celem i przeznaczeniem człowieka jest bowiem według jego koncepcji zdobycie (posiadanie) Boga. Bóg objawia się człowiekowi odpowiednio do jego natury, to znaczy dla uczucia jako dobro i piękno, dla umysłu jako światło i prawda, dla woli jako prawo i przykazanie. Relacja Boga do człowieka jest potrójna i staje się przez każdą władzę, ale równocześnie jest jedna, bo wszystkie władze są jednością w człowieku. Jednak według P. Semenenki dopiero na poziomie woli staje się ta relacja relacją osobistą - osoby do osoby ${ }^{38}$. Ale natura człowieka sama przez siebie nie ma zdolności adekwatnego do jego istoty zjednoczenia się z Bogiem. Dlatego został on obdarzony nadnatura, którą P. Semenenko widzi jako zdolność do życia nadprzyrodzonego, poznawania i kochania Boga zgodnie z Jego naturą. Dzięki nadnaturze natura człowieka była czysta i święta, jednak przez grzech pierworodny człowiek utracił nadnaturę i w konsekwencji zepsuł swoją naturę - stracił cel, a władze natury zapanowały nad nim, zamiast mu służyć. Utracona nadnatura została przywrócona dzięki Chrystusowi i jest przywracana ciągle przez sakramenty, głównie chrzest święty, który wszczepia w człowieka nowe nadprzyrodzone zalążki: łaskę uświęcająca, rozumianą jako zdolność skłaniania się duszy ku aktom

${ }^{36}$ Por. S. Pawlicki, Mózg i dusza, Kraków 1874, za: F. Gabryl, dz. cyt., s. 245-246.

${ }^{37}$ Por. tenże, Materializm wobec nauki, „Przegląd Polski” 3 (1869-1870), s. 45-86, 213-251; 4 (1869-1870), s. 35-90, za: F. Gabryl, dz. cyt., s. 240-245.

${ }^{38}$ Por. P. Semenenko, Mistyka, s. 24-25. 
wiary, nadziei i miłości, które podnoszą władze natury: wiara - rozum, nadzieja-uczucie, miłość - wolę ${ }^{39}$.

Na wiarę jako zdolność i możliwość ubogacania ludzkiego rozumu i poznania wskazuje również Walerian Kalinka. Jak stwierdza, zarówno na duszę każdego człowieka, jak i na jakikolwiek naród należy patrzeć oczyma wiary, aby widzieć, jaki człowiek czy naród jest przed Bogiem, w jego zamiarach i wartości. Bóg bowiem każdemu jako jednostce i jako wspólnocie naznaczył miejsce w społeczeństwie, które nakłada nań pewne obowiązki, którym nie można się bez grzechu sprzeniewierzaćc ${ }^{40}$. Widać tu nie tylko akceptację dla koncepcji uszlachetnienia człowieka przez wiarę, ale również wskazanie na podobną koncepcję prawdy jako zgodności z Bożą ideą.

Wracając do koncepcji człowieka P. Semenenki, uważa on, że osoba ludzka sama z siebie jest nicością, którą człowiek musi jakoś zapełnić. I zapełnia ją albo Bogiem albo fałszywymi przedmiotami z życia. W drugim przypadku osoba człowieka staje się jego początkiem i końcem oraz środkiem życia. Stan łaski zaś jest narzędziem, dzięki któremu człowiek może zmienić życie przyrodzone w nadprzyrodzone, gdzie to Bóg staje się początkiem i końcem, i samym życiem - zjednoczenie osoby Boga z osobą człowieka zachowuje osobę człowieka, ale zmienia wypełniającą ją treść. Treścią staje się Chrystus ${ }^{41}$. Również P. Smolikowski widzi człowieka jako swego rodzaju „teren” walki dobra i zła. Ludzie, skutkiem grzechu pierworodnego, posiadają w sobie jednocześnie nasienie zła i dobra. Zarówno niemożność zauważenia w człowieku całego dobra, jak i całego zła, które realizuje lub może realizować, jest wynikiem nieodpowiedniego i niedostatecznego jego poznania. Jednak mimo całego zła ludzie mogą stać się dobrymi i mimo całego swojego dobra mogą stać się złymi, co zależy tylko od użytku ich woli. Zatem to właśnie wolę należy rozwijać i to ona wyrasta na najważniejszą władzę człowieka ${ }^{42}$.

Pewne odbicie takiego ujęcia bytu oraz koncepcji człowieka można również zobaczyć w historiozofii ks. P. Semenenki, który odwołuje się w niej do aktu boskiej kreacji. Stwierdza, że ponieważ świat duchowy nie został stworzony na pierwsze słowo Boga bez swojego udziału, tak jak świat zmysłowy, musi ciagle samodzielnie przyczyniać się do swojego stworzenia. Celem ludzkich dążeń oraz przyczyną i powodem stworzenia jest niebo i zbawienie, więc dzieje świata duchowego rozwijają się i powinny rozwijać

39 Tamże, s. 25--34.

${ }^{40}$ W. Kalinka, Rozmyślania nad konstytucjami. Opr. A. Duda CR, Kraków 1996, s. $32-42$.

${ }^{41}$ Por. P. Semenenko, Mistyka, s. 30-31.

${ }^{42}$ Por. P. Smolikowski, O wychowaniu, Kraków 2010, s. 84-91. 
tak, jak porządek stworzenia. Stąd wyróżnia sześć okresów historii ludzkiej, po nich nastapi siódmy - okres pokoju i triumfu ${ }^{43}$, ostatecznego zwycięstwa Chrystusa.

\section{Rola teologii i wiary w rozwoju wychowawczym czlowieka}

$\mathrm{Na}$ koniec ważne wdaje się również rozróżnienie pomiędzy filozofią a teologią. Stanowisko P. Semenenki aprobuje przenikanie się obydwu, sprzeciwiając się mocnemu odróżnianiu teologii i filozofii, jakie można później spotkać na przykład u S. Pawlickiego. Według tego ostatniego teologia wykłada prawdy, do których człowiek swoim rozumem samodzielnie nie potrafi dojść, filozofia zaś zajmuje się tym, co rozum może wiedzieć sam z siebie ${ }^{44}$. Obie zatem mogą istnieć obok siebie, nie wchodząc ze sobą w konflikt. Natomiast P. Semenenko stwierdza, że filozofia opiera się na rozumie, ale w człowieku istnieje jeszcze uczucie i wola, którego pokarmem staje się właśnie wiara i teologia ${ }^{45}$ - dlatego ich współistnienie i współdziałanie jest nie tylko możliwe, ale znaczące i potrzebne. Jak się wydaje, wiąże się ten sposób rozumienia relacji między wiarą i rozumem, teologią i filozofią, z definicją wiary P. Semenenki. Otóż według niego „wiara jest jednym ze sposobów, któremi człowiek poznaje prawdę"46. W dalszym ciągu swych rozmyślań zaznacza, że „wiedza i wiara koniecznie odnoszą się do siebie, bo jakkolwiek się opierają na innych danych, są jednakowoż i podobne do siebie, bo są czynami jednego i tegoż samego rozumu, dokonanemi przez też same jego władze" ${ }^{\text {"47 }}$. Zatem zarówno wiara, jak i poznanie naukowe, teologia, jak i filozofia (traktowana jako narzędzie poznania racjonalnego utożsamianego $\mathrm{z}$ poznaniem naukowym ${ }^{48}$ ) są potrzebne człowiekowi i nie mogą istnieć oddzielnie bez szkody dla jego wszechstronnego rozwoju.

\section{Tomizm a myśl filozoficzna Piotra Semenenki}

Przyglądając się kluczowym kwestiom filozoficznych podstaw pedagogii zmartwychwstańczej wyłożonych przez P. Semenenkę, można zauważyć

${ }^{43}$ Por. F. Gabryl, dz. cyt., s. 228-229.

${ }^{44}$ Por. S. Pawlicki, Kilka uwag o podstawie i granicach filozofii, Kraków 1878, za: F. Gabryl, dz. cyt., s. 239-240.

${ }^{45}$ Por. F. Gabryl, dz. cyt., s. 210.

${ }^{46}$ P. Semenenko, Credo, s. 6.

47 Tamże, s. 9.

48 Por. T. Kaszuba, Semenenki, s. 8-26. 
niewątpliwe odniesienia do tomizmu. Byt składający się z materii i formy, proces poznawania, koncepcja władz, ujęcie duszy ludzkiej - wszystko to mocno nawiązuje do systemu filozoficznego św. Tomasza z Akwinu. Uderza jednak oryginalność myśli filozoficznej P. Semenenki - można powiedzieć, że czujemy myśl inspiratora odnowy tomizmu (współautora memoriału). Odbieganie od utartych schematów, a także podejmowanie prób pogodzenia tomizmu oraz nowożytnych koncepcji filozoficznych w spójną całość, zdaje się być świadome i zamierzone. Co szczególnie interesujące, stanowisk filozoficznych uważanych powszechnie za przeciwstawne: racjonalizmu i materializmu, subiektywizmu i obiektywizmu ${ }^{49}$. I chociaż próby zasymilowania pozytywnych fragmentów filozofii nowoczesnej w pewnych momentach prowadzą go stronę idealizmu, to podejmuje on próby przezwyciężenia tych trudności ${ }^{50}$. Charakterystycznym rysem całej filozofii P. Semenenki według T. Kaszuby pozostaje jednak próba stworzenia nowej, naukowej, chrześcijańskiej wizji świata ${ }^{51}$.

Oryginalność ujęcia wyraża się przykładowo w koncepcji trójpodziału istnienia i poznania rzeczy, która szerzej ujmuje rzeczywistość niż klasyczny tomizm, interpretujący byt w aspektach materii i formy, aktu i możności $^{52}$. Widoczna jest również w chęci uzupełnienia przez P. Semenenkę tomizmu o kwestie dotyczace koncepcji przedmiotu filozofii oraz pierwszej idei, co według T. Kaszuby wiąże się ze stworzeniem nowoczesnej wersji iluminizmu (po pierwsze, byt i jego składniki są niesamodzielne, potrzebują zatwierdzenia bytu absolutnego - Boga, pod drugie, kwestia światła intelektualnego jako drogi poznania na drodze nauki i wiary) ${ }^{53}$. Jednak te odstępstwa od tomizmu, tworzące szczególny i niepowtarzalny koloryt filozoficznej koncepcji P. Semenenki, stawały się również podstawą krytyki tego systemu. Zastrzeżenia dotyczące wprowadzenia siły jednoczącej pomiędzy formę i jestestwo wysuwa F. Gabryl, wskazując, że u Tomasza Akwinaty siła należy do przypadłości, istnieje istnieniem substancji. Jeśli u P. Semenenki owa siła między dwoma składnikami bytu jest samodzielna, zachodzi możliwość rozbicia jedności metafizycznej jestestwa na szereg pomniejszych form, jestestw i sil${ }^{54}$, czego tomizm nie dopuszcza. W kwestiach epistemo-

${ }^{49}$ Por. tenże, Trójpodziat, s. 6-7.

${ }^{50}$ Por. tenże, Piotr Semenenko i jego rozumienie tomizmu, http://www.biz.xcr.pl/files/ Kaszuba-Semenenko-i-tomizm.pdf, z dn. 3 sierpnia 2013 roku, s. 4-9.

${ }^{51}$ Por. tenże, Niektóre charakterystyczne elementy filozofii księdza Piotra Semenenki $C R$, http://www.biz.xcr.pl/files/Kaszuba-Filozofia-Semenenki.pdf, z dn. 3 sierpnia 2013 r.

${ }_{52}$ Por. tenże, Zasadność trójpodziału bytu w filozofii księdza Piotra Semenenki CR (próba oceny), Lublin 1963, s. 72.

${ }_{53}$ Por. tenże, Piotr, s. 4-9.

54 Por. F. Gabryl, dz. cyt., s. 225. 
logicznych zaś wskazuje F. Gabryl na fakt, iż w tomizmie podkreślano, że obrazy rzeczy są tym, przez co człowiek poznaje rzeczy, ale może również poznać same rzeczy, nie tylko ich obrazy. Teoria poznania i sposób definiowania prawdy u P. Semenenki zakładają zaś poznanie tylko formy, czyli obrazu rzeczy. Wątpliwości budzi również opis procesu poznania, w którym zabrakło rozważań o ścisłości chwytania rzeczy myślą. U P. Semenenki pojawia się uznanie bezproblemowości poznania, co wydaje się daleko idącym uproszczeniem. Zastrzeżenia wysnuwa również F. Gabryl w kwestii rozumienia prawdy, której koncepcja u P. Semenenki wydaje się odnosić jedynie do prawdy ontologicznej w węższym rozumieniu, a nie nadaje się do prawdy logicznej. Zasada tożsamości zaś powinna być według niego uznana za pierwszą, nie ostatnią - najpierw uchwycić trzeba byt jako identyczny ze sobą, by zastanawiać się potem nad jego formą i przyczyną ${ }^{55}$.

Pomimo szeroko zakreślonej krytyki systemu filozoficznego Piotra Semenenki, koncentrującej się na punktowaniu obszarów i kwestii stanowiących odstępstwa od tomizmu, która być może przyczyniła się w pewnym stopniu do usunięcia w cień pism tego filozofa, przedstawiona powyżej w dużym skrócie koncepcja wydaje się jednak interesująca i warta uwagi. Ta oryginalna myśl filozoficzna legła u podstaw systemu pedagogicznego działającego długi okres czasu w wielu krajach świata, a zainteresowania jej twórcy doprowadziły do zwrotu ku tomizmowi w Kościele katolickim i w konsekwencji powstania pedagogiki tomistycznej. Takie dokonania muszą sytuować ją w kręgu zainteresowań zarówno pedagogów, jak i filozofów, szczególnie o orientacji neotomistycznej i personalistycznej ${ }^{56}$.

\section{Podsumowanie}

W powyższych rozważaniach dominuje jedynie skrótowy opis myśli filozoficznej P. Semenenki, na co tylko pozwala formuła artykułu. Opracowa-

55 Por. tamże, s. 223-225.

56 Tomizm (neotomizm) oraz personalizm dzięki wielu powiązaniom i społecznym skojarzeniom z nauką Kościoła katolickiego częstokroć są traktowane jako jedno, i określane wspólną nazwą personalizmu. Jednak różnice pomiędzy powyższymi koncepcjami filozoficznymi i wynikającymi z nich konsekwencjami pedagogicznymi są znaczne i dotykają kwestii najbardziej istotnych: założeń ontologicznych i epistemologicznych. I chociaż współcześnie twórczy dialog pomiędzy neotomizmem a personalizmem, pozwalający na wzajemne uzupełnianie się, został nawiązany, to jednak pozostają one nurtami odmiennymi i warto pamiętać o ich rozróżnianiu. Ciekawe opracowanie dotyczące podobieństw i różnic oraz obszarów dialogu pomiędzy powyższymi koncepcjami filozoficznymi, a także wynikających z niego konsekwencji dla wychowania i kształcenia, można odnaleźć w artykule Jarosława Horowskiego. Por. J. Horowski, Tomistyczna myśl pedagogiczna w Polsce wobec idei personalizmu, „Kwartalnik Pedagogiczny” 2 (2011), s. 29-60. 
nia powstające na ten temat albo mają już wiele lat, albo są zupełnie świeże. Chyba dlatego też oryginalna i interesująca myśl filozoficzna leżąca u podstaw systemu wychowawczego zmartwychwstańców jest współcześnie dość słabo rozpoznana i rozpowszechniona, pomimo swoich niezaprzeczalnych walorów poznawczych. Jak się wydaje, powinny być podejmowane dalsze, dokładne próby jej rekonstrukcji, przy jednoczesnym wskazywaniu na jej znaczenie i obecność głównie w pedagogii prowadzonej przez Zgromadzenie oo. Zmartwychwstańców przed odzyskaniem przez Polskę niepodległości (i na jej rzecz) oraz w 20-leciu międzywojennym. Wykraczanie poza tradycyjnie ujmowany tomizm może być niezwykle inspirujące i nie może stanowić powodu odrzucania tej refleksji filozoficznej, a jej uwzględnienie i rozpoznanie może wiele wnieść zarówno do rzeczywistości filozoficznej, jak i pedagogicznej.

\section{Philosophical Basis of Resurrectionists' Pedagogical System in Writings by Piotr Semenenko (Summary)}

In the works by Piotr Semenenko, as well as other authors of the Congregation of the Resurrection one can find an original and innovative system of philosophy which tries to update scholastic philosophy and reconcile it with some concepts of modern philosophy recognized as valuable. Echoes of the philosophical system are present in educational and didactic practices of Resurrectionists, however their contribution to introduction of Neo-Thomism to pedagogy is underestimated nowadays. Hereof deliberations try to present some key concepts on fundamental ontological and epistemological issues, as well as anthropological which can be found among cofounders of the congregation. Original picture of Thomism by Semenenko can be really inspiring for philosophers, as well as for researchers of Resurrectionists' education system of pedagogues.

Keywords: Resurrectionist; philosophy; pedagogy; Thomism; Semenenko.

\section{Filozoficzne podstawy systemu pedagogicznego zmartwychwstańców w pismach Piotra Semenenki (Streszczenie)}

W dziełach Piotra Semenenki oraz innych twórców systemu pedagogicznego Zgromadzenia oo. Zmartwychwstańców można odnaleźć oryginalny i nowatorski system filozoficzny, próbujący zaktualizować filozofię scholastyczną (tomistyczną) 
Filozoficzne podstawy systemu pedagogicznego zmartwychwstańców... 161

i pogodzić ją z pewnymi uznanymi za wartościowe koncepcjami filozofii nowożytnej. Echa tego systemu filozoficznego obecne są w praktyce wychowawczej i dydaktycznej zmartwychwstańców, choć ich wkład we wprowadzenie neotomizmu do pedagogiki jest współcześnie niedoceniany. W niniejszych rozważaniach staram się przedstawić pewne podstawowe koncepcje dotyczące fundamentalnych kwestii ontologicznych i epistemologicznych, a także antropologicznych, jakie można odnaleźć wśród założycieli tego zgromadzenia. Oryginalne ujęcie tomizmu P. Semenenki może bowiem być bardzo inspirujące zarówno dla filozofów, jak i dla badających zmartwychwstańczy system edukacyjny pedagogów.

Słowa kluczowe: zmartwychwstańcy; filozofia; pedagogia; tomizm; Semenenko. 
